\title{
NUMERICAL EVALUATION OF GRASSLANDS DOMINATED BY SESLERIA JUNCIFOLIA AGG. IN SERBIA
}

\author{
Eva KABAŠ ${ }^{1, *}$, Snežana VUKOJIČIĆ́ ${ }^{1}$, Antun ALEGRO ${ }^{2}$, Boštjan SURINA ${ }^{3}$, \\ Nevena KUZMANOVIĆ ${ }^{1}$, Vedran ŠEGOTA ${ }^{4} \&$ Dmitar LAKUŠIĆ$^{1}$
}

\begin{abstract}
Phytosociological and numerical analyses of grasslands dominated by Sesleria juncifolia s.l. in Serbia were performed in order to resolve their syntaxonomy and nomenclature. Twelve relevés were sampled on Mt. Mučanj (western Serbia), which were then compared with similar relevés from other parts of the Balkan Peninsula by means of numerical analyses. The relevés were classified using cluster analysis, while the ordination was conducted using Detrended Correspondence Analysis (DCA). The results suggest the occurrence of two floristically well defined Dinaric associations in Serbia: Seslerio juncifoliae-Edraianthetum graminifolii ass. nova from Mt. Mokra Gora (Oxytropidion urumovii, Elyno-Seslerietea) and Diantho petraeae-Seslerietum juncifoliae ass. nova (Chrysopogono-Saturejion, Festuco-Brometea) from Mt. Mučanj.
\end{abstract}

Key words: Balkan Peninsula, classification, ordination, Seslerietum juncifoliae s.l., syntaxonomy, vegetation.

\section{Izvleček}

Naredili smo fitocenološko in numerično analizo travišč v katerih prevladuje vrsta Sesleria juncifolia s.l. in predstavili sintaksonomske in nomenklaturne rešitve. Dvanajst vegetacijskih popisov smo naredili na gori Mučanj (zahodna Srbija) in jih z numeričnimi metodami primerjali s podobnimi popisi z drugih delov Balkanskega polotoka. Popise smo klasificirali s klastrsko metodo, za ordinacijo smo uporabili korespondenčno analizo z odstranjenim trendom (DCA). Rezultati kažejo na obstoj dveh floristično dobro utemeljenih dinarskih endemičnih asociacij v Srbiji: Seslerio juncifoliae-Edraianthetum graminifolii ass. nova z Mokre Gore (Oxytropidion urumovii, Elyno-Seslerietea) in Diantho petraeae-Seslerietum juncifoliae ass. nova (Chrysopogono-Saturejion, Festuco-Brometea) z gore Mučanj.

Ključne besede: Balkanski polotok, klasifikacija, ordinacija, Seslerietum juncifoliae s.l., sintaksonomija, vegetacija.

\section{INTRODUCTION}

The genus Sesleria Scop. (Poaceae, Pooideae, Seslerieae) is one of the most important and interesting grass genera with its' centre of diversity and distribution on the Balkan Peninsula. The species of this genus play a very important role in the development of different types of grasslands along wide elevational and latitudinal gradients, forming syntaxa at various ranks - Seslerietum korabiensis Micevski 1994, Seslerietum wettsteinii Horvat 1937, Seslerietum juncifoliae Horvat 1930, Seslerion juncifoliae Horvat 1930, Seslerion rigidae Zólyómi 1939, Seslerietalia juncifoliae Horvat 1930,

\footnotetext{
${ }^{1}$ Institute of Botany and Botanical Garden Jevremovac, Faculty of Biology, University of Belgrade, Takovska 43, 11000 Belgrade, Serbia, ekabas@bio.bg.ac.rs*, dlakusic@bio.bg.ac.rs, nkuzmanovic@)bio.bg.ac.rs, sneza@bio.bg.ac.rs

${ }^{2}$ Department of Botany, Faculty of Science, University of Zagreb, Marulicevev trg 20/II, 10000 Zagreb, Croatia, antun. alegro@biol.pmf.hr

${ }^{3}$ Faculty of Mathematics, Natural Sciences and Information Technologies, University of Primorska, Glagoljaška 8, 6000 Koper, Slovenia, bostjan.surina@prirodoslovni.com

${ }^{4}$ Institute for Research and Development of Sustainable Ecosystems, Jagodno 100a, 10415 Novo Cice, Velika Gorica, Croatia, vsegota@ires.hr
} 
etc. However, their most important role is forming the grasslands on base-rich soils of alpine and subalpine belts of temperate European mountain ranges (class Elyno-Seslerietea Br.-Bl. 1948). The domination by Sesleria species of the high mountain calcareous plant communities in Europe is discussed by Petriccione (1995) in his overview of this vegetation type.

Sesleria juncifolia agg. represents an amphiAdriatic group of taxa exhibiting a typical disjunct range including the western \& central Balkans and the Apennine Peninsula, where neither their systematic relationships nor the syntaxonomical scheme are entirely clear. Based on relevant taxonomic papers (Deyl 1980, Strgar 1981, Alegro 2007, Di Pietro 2007), the following species are considered to belong to $S$. juncifolia agg.: S. apennina Ujhelyi, S. calabrica (Deyl) Di Pietro, S. kalnikensis Jávorka, S. juncifolia Suffren, $S$. interrupta Vis., S. ujhelyii Strgar and S. albanica Ujhelyi. Since both names, S. juncifolia Suffren 1802 and S. tenuifolia Shrader 1806, were validly published, we use the earlier legitimate name $S$. juncifolia in this paper, as it has a priority according to Art 11.4 of ICN (McNeill et al. 2012). The detailed discussion regarding the nomenclatural issues in Sesleria juncifolia complex is provided in Di Pietro et al. (2013).

For the territory of Serbia, Lakušić \& Sabovljević (2005) proposed a classification scheme in which 31 associations and eight subassociations dominanted by different Sesleria species were included, belonging to five classes, seven orders and 11 alliances. However, this classification was not based on serious numerical analyses, thus an objective circumscription and classification are still missing. The most investigated grasslands dominated by Sesleria spp. belong to the class Elyno-Seslerietea, order Seslerietalia juncifoliae (=tenuifoliae) Horvat 1930, alliances Seslerion rigidae Zólyómi 1939 (dry grasslands on calcareous bedrock) and Seslerion rigidae-latifoliae D. Lakušić 1996 prov. (dry grasslands on serpentine rocks). Furthermore, seven associations belong to the order Onobrychido-Seslerietalia Horvat 1949, alliances Edraiantho-Seslerion Horvat 1949, Onobrychido-Festucion Horvat 1949 and Seslerio-Festucion R. Jovanović 1955. A significant number of communities belong to the class of alpine pastures on siliceous rocks, Caricetea curvulae Br.-Bl. 1948, order Seslerietalia comosae Simon 1957, alliance Seslerion comosae Horvat 1935. Only one association was recorded for the class Asple- nietea trichomanis Br.-Bl. 1934 corr. Oberd. 1977. Finally, some communities dominated by Sesleria spp. belong to the Festuco-Brometea Br.-Bl. \& Tx. ex Soó 1947. The dominant Sesleria species that build up these syntaxa are S. filifolia Hoppe in eastern Serbia and S. serbica (Adam.) Ujhelyi and S. juncifolia in western Serbia.

Our research only included the stands dominated by Sesleria juncifolia agg. described as associations Seslerio-Edraianthetumjugoslavici Petković et al. 1990 (Petković et al. 1990) from Mt. Mokra Gora, Seslerietum tenuifoliae S. Vukojičić \& D. Lakušić 1990 prov. (Stanić 1990) from Mt. Mučanj and Carici laevis-Helianthemetum alpestre Horvat 1930 seslerietosum tenuifoliae Rajevski 1990 from Mt. Šarplanina (Rajevski 1990) in Serbia.

\section{MATERIALS AND METHODS}

Data sampling. In order to describe and resolve the syntaxonomy of the Serbian grasslands dominated by Sesleria juncifolia agg., we processed 139 relevés belonging to 13 syntaxa dominated by $S$. juncifolia agg., distributed throughout the territory of Serbia, Bosnia and Herzegovina, Montenegro, Croatia, Slovenia and northeastern Italy. The majority of the relevés were taken from literature sources. The main criterion for the selection of the syntaxa to be included in the analyses was that $S$. juncifolia appears as both the dominant and nominal species in the name of a syntaxa, either at association or subassociation level (Table 1). In addition to the literature data, personal unpublished data previously gathered on Mt. Mučanj in Serbia, Mt. Durmitor in Montenegro and areas of Mts. Velebit (Croatia) and Snežnik (Slovenia; Table 1, Figure 1) were also included in the analyses. All the relevés were sampled according to Braun-Blanquet (1964) method. The plot size of our own relevés was $25 \mathrm{~m}^{2}$, corresponding to the standard for grasslands proposed by Chytrý \& Otýpková (2003). Plot sizes of relevés from the literature varied, the exact sizes for each association are given in Table 1.

Data analysis. After transforming BraunBlanquet cover-abundance values into a ninedegree ordinal scale (van der Maarel 1979) the relevés were subjected to Detrended Correspondence Analysis (DCA) in order to detect the basic structure of the floristic composition. Finally, the complete set was classified using Bray-Curtis similarity and group average clustering. These 


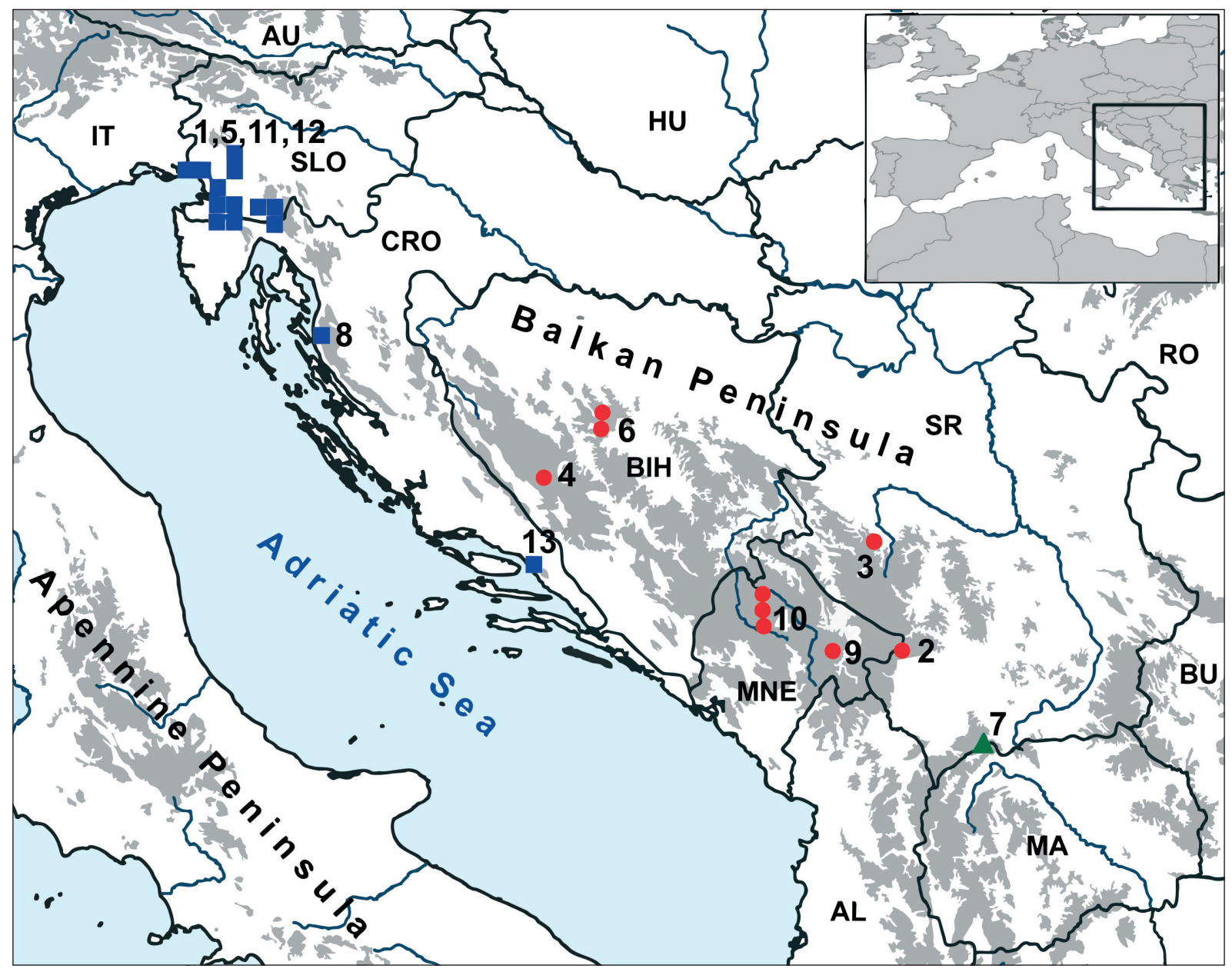

Figure 1: The map of the localities of analyzed syntaxa. Numbers on the map correspond to ordinal numbers in Table 1. Blue squares correspond to groups A and C, red dots and green triangle (stands from Mt. Šarplanina excluded from second step of analysis) correspond to group B from Figure 2. Both dots and squares correspond with UTM 10 x 10 squares. Area above $1000 \mathrm{~m}$ a.s.l. is shaded. Country abbreviation: IT - Italy, SLO - Slovenia, CRO - Croatia, HU - Hungary, BIH - Bosnia and Herzegovina, SR - Serbia, MNE - Montenegro, RO - Romania, BU - Bulgaria, MA - Macedonia, AL - Albania.

Slika 1: Karta lokacij proučevanih sintaksonov. Številke na karti so enake kot v Tabeli 1. Modri kvadrati ustrezajo skupinama A in C, rdeči krožci in zeleni trikotniki (sestoji s Šarplanine so izvzeti iz drugega koraka v analizi) ustrezajo skupini B na Sliki 2. Krožci in kvadrati se ujemajo z UTM 10 x 10 kvadranti. Območja nad 1000 m nad morjem so osenčena. Okrajšave držav: IT - Italija, SLO - Slovenija, CRO - Hrvaška, HU - Madžarska, BIH - Bosna in Hercegovina, SR - Srbija, MNE - Črna gora, RO - Romunija, BU - Bolgarija, MA - Makedonija, AL - Albanija.

analyses were processed using PcOrd 6.0 (McCune \& Mefford 2011) and FLORA softwares (Karadžić et al. 1998).

In this paper, we used the concept of diagnostic and dominant species proposed by Chytrý et al. (2002), Chytrý \& Tichý (2003) and Tichý \& Chytrý (2006). Using the statistical measures of fidelity, we quantified concentrations of species occurrences in groups of classified sites in order to determine diagnostic species (Chytrý et al. 2002). The size of the site groups in the data set was standardised (virtually equalized), while the relative frequencies of species occurrence within and outside of these groups were kept constant (Tichý and Chytrý 2006) to calculate the $\Phi$-values as a measure of fidelity independent of the number of available relevés. To assess statistical significance of concentration of species in vegetatation types, we performed the Monte Carlo significance test of observed maximum indicator value for the species with 4999 permutations. PcOrd 6.0 software (McCune \& Mefford 2011) was used for the calculation of $\Phi$-values. In order to determine the dominant species, we 
calculated the coverage index (Ic) according to Lausi et al. (1982). Species with $\Phi$-values higher than 0.50 were considered diagnostic. Species with cover $\geq 50 \%$ in a minimum of $5 \%$ of the relevés for any association were accepted as dominant. Species recorded in a minimum of $60 \%$ of the relevés for any association were considered constant. Nomenclature of plant taxa follows the Flora Europaea Database (Tutin et al. 2001), except for critical taxa with unresolved relationships, which were included as species complexes (aggregates). The names of all the syntaxa follow Rodwell et al. (2002) with a few exceptions according to Lakušić \& Sabovljević (2005). All the underlying plot data used in the paper are stored in Vegetation Database of Grassland Vegetation in Serbia (Aćić et al. 2012; GIVD number: EURS-002; relevé numbers: 7000-7138).

\section{RESULTS}

Ordination - A DCA conducted on the complete data set showed three rather discrete groups of relevés (Figure 2), well separated along first two canonical axes. The most distinct (Group I) was the one representing relevés of the Rhododendro hirsuti-funiperetum alpinae seslerietosum tenuifoliae from the Liburnian karst. The remaining two groups represented the relevés from northeastern Italy, Slovenia and Croatia (Group II), and the relevés from Serbia, Bosnia and Herzegovina and Montenegro (Group III). It can also be seen that the relevés from Mt. Mučanj (western Serbia) and the ones representing the Seslerio-Edraianthetum jugoslavici (Mt. Mokra Gora) were well differentiated within this last group, while the relevés representing the Carici laevis-Helianthemetum alpestre seslerietosum tenuifoliae from Mt. Šarplanina overlapped with the rest of the relevés in this group.

Classification - Results of the cluster analysis performed on the complete data set were very much in accordance with the ordination results, in that they showed that two main groups of stands (clusters) could be differentiated. Cluster I (Figure 3) corresponded to the stands of the associations from northeastern Italy, Slovenia and Croatia. This cluster corresponded completely with Groups I and II in Figure 2, so the only difference is related to relevés of Liburnian heaths Rhododendro hirsuti-funiperetum alpinae seslerietosum tenuifoliae, which were differentiated as a single group in DCA. On the other hand, Cluster II (Figure 3) represented the relevés from Serbia, Bosnia and Herzegovina and Montenegro (Group III in Figure 2). Within this cluster,

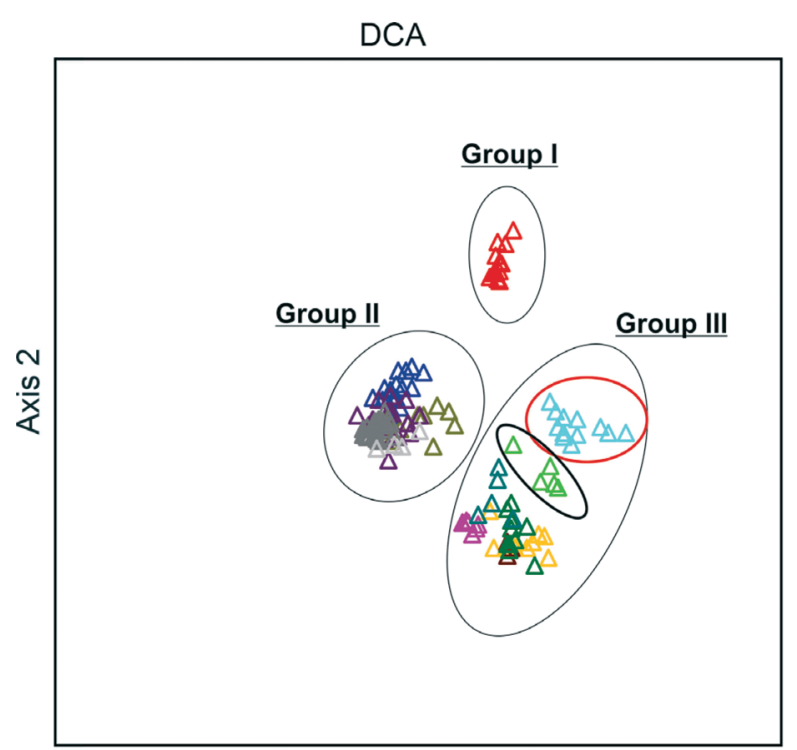

Axis 1

\section{Group I}

$\Delta$ Rhododendro hrisuti-Juniperetum alpinae, Slovenia \& Croatia

\section{Group II}

$\triangle$ Carici humilis-Seslerietum juncifoliae, Mt. Velebit

$\Delta$ Seslerietum juncifoliae, Mt. Snežnik

$\Delta$ Carici humilis-Centaureetum rupestris, Slovenia \& Italy

$\triangle$ Bromo-Seslerietum interruptae, Mt. Biokovo

$\Delta$ Genisto sericeae-Seslerietum juncifoliae, Slovenia \& Italy

\section{Group III}

$\triangle$ Seslerio juncifoliae-Edraianthetum graminifolii, Mt. Mokra gora

$\triangle$ Diantho petreae-Seslerietum juncifoliae, Mt. Mučanj]

$\Delta$ Seslerietum juncifoliae, Mt. Cincar

$\Delta$ Carici laevis-Helianthemetum alpestre, Mt. Šar-planina

$\Delta$ Carici laevis-Seslerietum juncifoliae, Mt. Bjelasica

$\triangle$ Seslerio-Gentianetum dinaricae, Mt. Vlašić

$\Delta$ Seslerietum juncifoliae, Mt. Durmitor

Figure 2: Detrended Correspondence Analysis (DCA) of stands of 13 grasslands dominated by Sesleria juncifolia from the Balkan Peninsula.

Slika 2: Korespondenčna analiza z odstranjenim trendom (DCA) sestojev 13 traviščnih združb v katerih prevladuje Sesleria juncifolia z Balkana. 


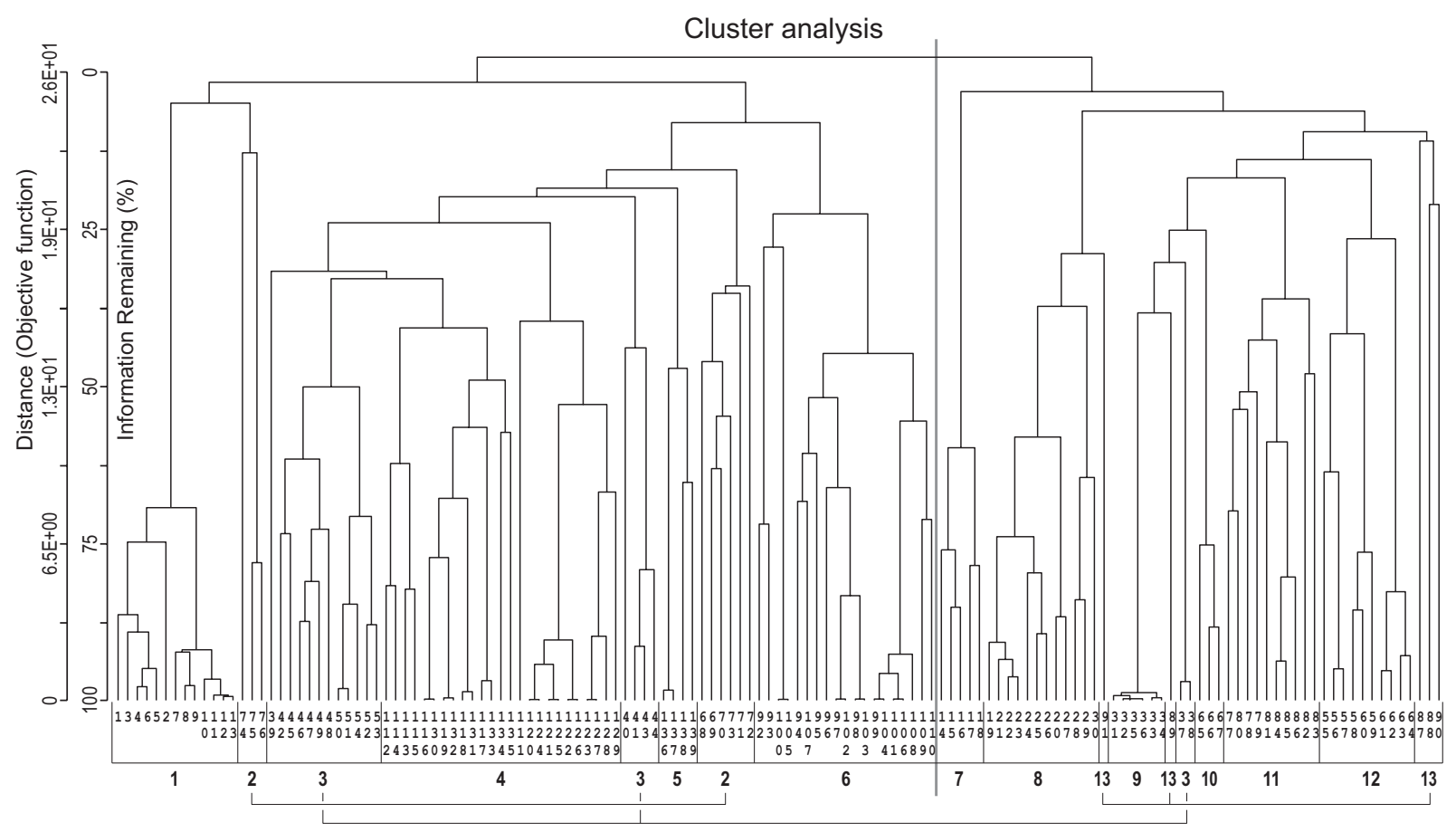

\section{Cluster I}

1) 1-13-Rhododendro hirsuti-Juniperetum alpinae, Slovenia and Croatia 2) 68-76-Carici humilis-Seslerietum juncifoliae, Mt. Velebit

3) 39-54 - Seslerietum juncifoliae, Mt. Snežnik

4) 111-135 - Carici humilis-Centaureetum rupestris, Slovenia and Italy

5) 136-139 - Bromo-Seslerietum interruptae, Mt. Biokovo

6) 092-110 - Genisto sericeae-Seslerietum juncifoliae, Slovenia and Italy

\section{Cluster II}

7) 14-18 - Edraiantho graminifoliae-Sesler. juncifoliae, Mt. Mokra gora 8) 19-30 - Diantho petrae-Seslerietum juncifoliae, Mt. Mučanj

9) 31-38-Seslerietum juncifoliae, Mt. Cincar

10) 65-67-Carici laevis-Helianthemetum alpestre, Mt. Šar planina

11) 77-86 - Carici laevis-Seslerietum juncifolia, Mt. Bjelasica

12) 55-64 - Seslerio-Gentianetum dinaricae, Mt. Vlašić

13) 87-91 - Seslerietum juncifoliae, Mt. Durmitor

Figure 3: Cluster Analysis of stands of 13 grasslands dominated by Sesleria juncifolia from the Balkan Peninsula. Slika 3: Klastrska analiza sestojev 13 traviščnih združb v katerih prevladuje Sesleria juncifolia z Balkana.

it was again noticeable that Serbian associations represented well separated and discrete units.

On the basis of the ordination and classification analyses, we established the existence of two well defined syntaxa with the dominance of Sesleria juncifolia in Serbia: ass. Seslerio-Edraianthetum jugoslavici from Mt. Mokra Gora, and a new association from Mt. Mučanj: Diantho petraeae-Seslerietum juncifoliae. Relevés of the Carici laevis-Helianthemetum alpestre seslerietosum tenuifoliae from Mt. Šarplanina overlapped with communities from the Cincar, Vlašić, Bjelasica and Durmitor mountains in the ordination, while in the cluster graph analysis they formed a joint cluster together with the community from Mt. Cincar and only a few relevés from the community from Mt. Durmitor. A synoptic table comparing all community types is presented in the Table 3 in order to show the differences between the individual clusters obtained by numerical classification.

\section{SyNTAXONOMICAL TREATMENT}

Ass. Diantho petraeae-Seslerietum juncifoliae Vukojičić \& D. Lakušić ass. nova hoc loco (Holotypus Table 2 , rel. 5 hoc loco)

Original: Seslerietum tenuifoliae Stanić \& D. Lakušić 1990 prov., nom. ined. (Art. 1, ICPN)

Note: The Seslerietum tenuifoliae Stanić \& D. Lakušić 1990 prov. was not effectively published (Def. III, Art. 1, ICPN; Weber et al. 2000), since it was only recorded and preliminarily described in a Diploma thesis (Stanić 1990). Therefore, we describe it here as a new association, in accordance with the International Code of Phytosociological Nomenclature (ICPN; Weber et al. 2000).

Dominant species: Sesleria juncifolia

Diagnostic species: Campanula rotundifolia, Chamaecytisus ciliatus, Chamaespartium sagittale, Cotoneaster integerrimus, Dianthus petraeus subsp. petraeus, Draba lasiocarpa, Festuca panciciana, Ga- 
lium corrudifolium, Helianthemum nummularium subsp. nummularium, Ornithogalum collinum, $P e^{-}$ dicularis heterodonta, Potentilla cinerea, Sanguisorba minor subsp. minor

Constant species: Carex kitaibeliana, Edraianthus graminifolius, Globularia cordifolia, Saxifraga paniculata

Diagnosis: Rocky calcareous grasslands at elevations between 1300 and $1450 \mathrm{~m}$ a.s.l., on the NW and W (rarely E) exposed slopes, with an inclination of about $35^{\circ}$ on average (Table 2). The dominant species Sesleria juncifolia with its dense tussocks formed stands up to $40 \mathrm{~cm}$ high, covering $25-80 \%$ (average $65 \%$ ) of the plots (Table 2). The average number of species per plot of $16 \mathrm{~m}^{2}$ was 26. Some Balkan endemic and Balkan-Carpathian or Balkan-Apennine subendemic species, such as Cerastium decalvans, Daphne blagayana, Dianthus petraeus subsp. petraeus, Draba lasiocarpa, Edraianthus graminifolius, Festuca panciciana, Laserpitium siler subsp. garganicum, Minuartia bosniaca, Pedicularis heterodonta and Sesleria juncifolia were recorded in this association. Also three glacial relicts (Arabis alpina, Poa alpina, and Saxifraga paniculata) occuring within the stands may point to the glacial-refugial character of the association. However, the occurrence of some differential taxa from forests, such as Daphne mezereum, Fagus sylvatica, and Poa nemoralis, could point to the fact that the montane beech forests of Fagetalia sylvaticae Pawłowski 1928 prevailed in the recent past, or might even represent a natural vegetation type on sites nowadays covered by the stands of the Diantho petraeae-Seslerietum juncifoliae.

\section{Ecology and synchorology of the association}

Stands of Diantho petraeae-Seslerietum juncifoliae are so far known only from the area of Mt. Mučanj in southwestern Serbia. The direction of the mountain is NW-SE, while its maximum height is $1534 \mathrm{~m}$ a.s.l. Mt. Mučanj is seperated from the neighboring mountains by river valleys, pointing to the fact that fluvial erosion was the factor shaping the relief, earlier formed by tectonic movements. The dominant geological substrate in this area is limestone. The soils are shallow and very skeletal. The climate type is temperate-continental, but in its modified mountain variant (Stanić 1990). The annual mean temperature is $2.9^{\circ} \mathrm{C}$, and the annual precipitation is $944 \mathrm{~mm}$. January is the coldest month with a temperature of $-8,5^{\circ} \mathrm{C}$, while July is the warmest with a temperature of $+12.3{ }^{\circ} \mathrm{C}$ (Stanić 1990). The wettest months are

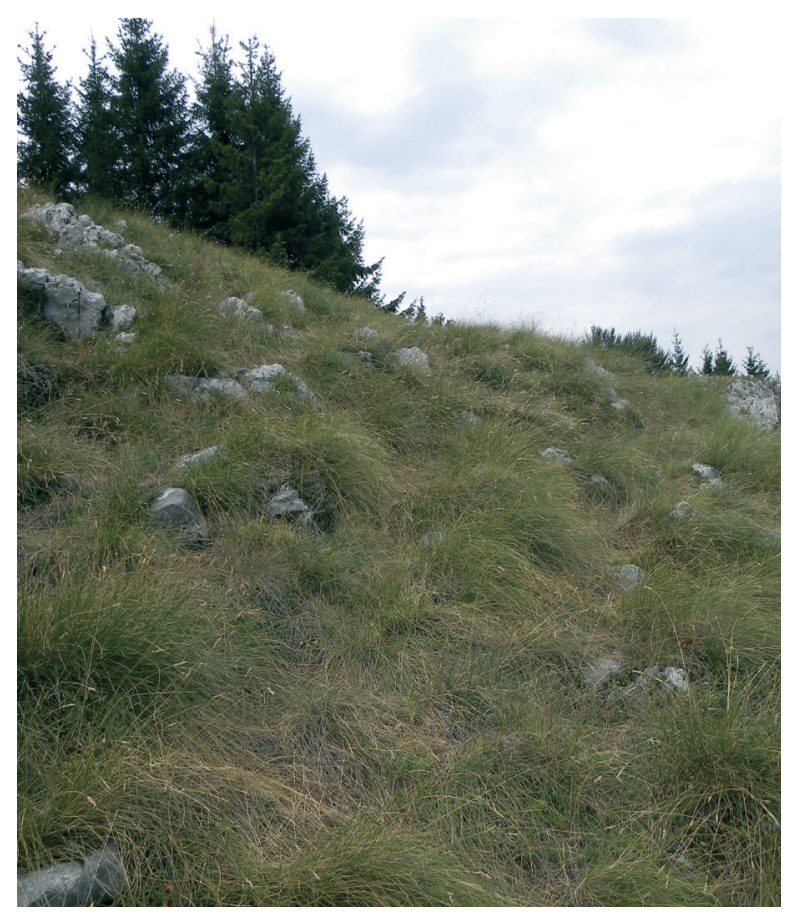

Figure 4: Summer aspect of the association Diantho petraeaeSeslerietum juncifoliae Vukojičić \& D. Lakušić ass. nova on Mt. Mučanj (photo: N. Kuzmanović).

Slika 4: Poletni aspekt asociacije Diantho petraeae-Seslerietum juncifoliae Vukojičić \& D. Lakušić ass. nova na gori Mučanj (foto: N. Kuzmanović).

May, June and August, while the driest are February and March. Mean monthly temperatures below $0{ }^{\circ} \mathrm{C}$ were noted during November, December, January, February and March, confining the growing season to between April and September. Considering the relatively low elevation and the mountain temperate climate, montane beech forests represent the potential vegetation of the investigated area. However, since the major parts of the forests were completely degraded, artificial forest stands of black pine (Pinus nigra), fir (Abies $a l b a$ ) and spruce (Picea abies) dominate the landscape (Stanić 1990).

Ass. Seslerio juncifoliae-Edraianthetum graminifolii B. Petković et al. ex Kabaš et al. ass. nov. hoc loco

Validated name: Seslerio-Edraianthetumjugoslavici Petković et al. 1990 nom. inval. (Art. 5, ICPN) Holotypus: Petković et al. (1990: Table 2, rel. 2)

Note: The association Seslerio-Edraianthetum jugoslavicii B. Petković et al. 1990 was not validly published, because the holotype relevé was not assigned (Art. 5, ICPN; Weber et al. 2000). Also, 
the name Edraianthus jugoslavicus Lakušić was not validly published (Art. 39.1 of ICN, McNeill et al. 2012), since it was not accompanied by a Latin description or diagnosis. Accordingly, we used the accepted and validly published name Edraianthus graminifolius (L.) A. DC. (Euro+Med 2010) when naming the association.

Diagnostic species: Acinos arvensis, Alchemilla plicatula, Alyssum montanum, Anthyllis vulneraria subsp. pulchella, Asplenium trichomanes-ramosum, Helianthemum nummularium subsp. grandiflorum, Juniperus sabina, Minuartia verna, Polygonum viviparum, Scabiosa ochroleuca, Silene pusilla, Polygala supina subsp. supina

\section{Syntaxonomical SCHEME}

\section{Festuco-Brometea Br.-Bl. \& Tx. ex Soó 1947}

Scorzonero-Chrysopogonetalia Horvat \& Horvatić 1958

Chrysopogono-Saturejion Horvat \& Horvatić 1934

Diantho petraeae-Seslerietum juncifoliae Vukojičić \& D. Lakušić 2014

Elyno-Seslerietea Br.-Bl. 1948

Crepidetalia dinaricae Lakušić 1966

Oxytropidion urumovii Lakušić 1964

Seslerio juncifoliae-Edraianthetum graminifolii Petković et al. ex Kabaš et al. 2014

\section{DISCUSSION}

Our numerical analyses showed that the analyzed stands of different syntaxa dominated by Sesleria juncifolia agg. in the mountains of the central and western part of the Balkan Peninsula are very heterogenous and probably have different origins. Their relationships in a broader, amphi-Adriatic context are a subject of the ongoing research, preliminarily presented in Di Pietro et al. (2013).

Our results showed that the first clearly distinct group (Group I, Figure 2) represents the stands of the Rhododendro hirsuti-funiperetum alpinae seslerietosum tenuifoliae. These results support the opinion of Surina (2013) that despite the domination of $S$. juncifolia in these stands, the syntaxon should actually be classified within the heath vegetation of Erico-Pinetea Horvat 1959, and not within the grassland communities of Elyno-Seslerietea. The second well differenti- ated group (Group II, Figure 2) corresponds to the stands from northwestern Italy, Slovenia and Croatia, representing grasslands classified mostly within the class Festuco-Brometea. Finally, the third well defined and separated group (Group III, Figure 2; Cluster II, Figure 3) includes Serbian, Bosnian and Herzegovinian and Montenegrian grassland stands, classified mostly within the vegetation of the high mountain rocky calcareous grasslands of the class Elyno-Seslerietea. Furthermore, both DCA and cluster analysis also showed that both Serbian associations are floristically well differentiated from the rest of the similar syntaxa, i.e. the association Seslerio juncifoliae-Edraianthetum graminifolii from Mt. Mokra Gora, along with the stands of the associations from the Bjelasica, Durmitor, Cincar and Vlašić mountains belonging to the class Elyno-Sesleriet$e a$. Corroboration of this statement can be seen in the floristic composition, which is determined by the position of these stands at high elevations, usually above the upper forest line.

The newly described association from Mt. Mučanj, on the other hand, significantly differs from the subalpine and alpine rocky grasslands of the class Elyno-Seslerietea in its floristic properties. These stands host 43 taxa (e.g., Briza media, Bromus erectus, Euphorbia myrsinites, Globularia cordifolia, Hieracium pilosella, Hypericum perforatum, Juniperus communis, Leucanthemum vulgare, Phleum pratense, Plantago lanceolata, Plantago media, Poa badensis, Potentilla cinerea, Sanguisorba minor, Teucrium chamaedrys, Thymus pulegioides, Trifolium campestre, Trifolium montanum etc.) which, within the eastern and southeastern Dinaric Alps, prefer calcareous grasslands developed within deciduous broadleaved forests. Additionally, the $\Phi$-indices of most of these taxa are highly statistically supported, hence we find their classification within the class Festuco-Brometea to be fully justified. The fact that only 12 taxa typical for subalpine and alpine grasslands (Acinos alpinus, Arabis alpina, Carex kitaibeliana, Daphne alpina, Edraianthus graminifolius, Helianthemum canum, Hieracium villosum, Pedicularis heterodonta, Poa alpina, Rosa pendulina, Sesleria juncifolia and Thlaspi kovatsii) occur in stands from Mt. Mučanj further supports our classification scheme. To that end, $\Phi$-indices of the majority of the subalpine and alpine grassland taxa from the class Elyno-Seslerietea do not reflect statistically significant fidelity or the diagnostic value for the association in general. 
Confirmation of the opinion that the new community from Mt. Mučanj belongs to the class of Festuco-Brometea should also be sought in its coenotic surroundings and its origin. The potential natural vegetation of the highest part of Mt. Mučanj is deciduous broadleaved forest of the Fagetalia sylvaticae order (Jovanović et al. 1986). Therefore, at an altitude of $1500 \mathrm{~m}$ a.s.l., this isolated mountain does not provide conditions for the development of the potential vegetation of (sub)alpine grasslands of the Elyno-Seslerietea class.

While there is no doubt the new association from Mt. Mučanj belongs to the class FestucoBrometea, and not Elyno-Seslerietea, as indicated in Lakušić \& Sabovljević (2005), its assignment to a lower syntaxa is not completely clear. Considering their geographic position and floristic composition, these stands show transitional characteristics connecting them to calcareous karstic grasslands of the Illyric-Dinaric region with Chrysopogono-Saturejion Horvat \& Horvatić 1934, meso-xerophytic swards in sub-oceanic regions of western Europe with Bromion erecti Koch 1926, and meso-xerophytic swards in sub-continental regions of central and eastern Europe with CirsioBrachypodion pinnati Hadač \& Klika 1944. The most important species connecting this association with the Chrysopogono-Saturejion are: Asperula cynanchica, Dianthus petraeus, Galium corrudifolium, Globularia cordifolia, Hieracium villosum, Laserpitium siler, Leontodon crispus, Sesleria juncifolia, and Teucrium chamaedrys. The species relating it with the associations of the alliance Bromion erecti are the following: Plantago media, Sanguisorba minor, Scabiosa columbaria, considered as diagnostic for the Bromion erecti (Dengler 2003, Jarolímek \& Šibík 2008, Chytrý 2010), while it also hosts diagnostic species of the Cirsio-Brachypodion pinnati (Dengler 2003, Jarolímek \& Šibík 2008, Chytrý 2010) such as Asperula cynanchica, Brachypodium pinnatum, Bromus erectus, Plantago media, Sanguisorba minor, Trifolium montanum. Therefore, considering the number of common species and their diagnostic character as well as their geographic position within the continental Dinarides, the authors think the position of the new association Diantho petraeae-Seslerietum juncifoliae is within the alliance Chrysopogono-Saturejion.

The presence of 11 chasmophytic taxa in the stand of the newly described association is also significant, when the syntaxonomic position and the origin of the association are considered. Specific chasmophytic taxa are present in rocky grasslands due to the proximity of chasmophytic stands in the investigated area (Stanić \& Lakušić 1993) and the fact that steep rocky grasslands share many features with rock crevices or even screes, generating ecological conditions suitable for both grassland and chasmophytic taxa, e.g. Asplenium ceterach, Asplenium ruta-muraria, Asplenium trichomanes, Campanula rotundifolia, Erysimum sylvestris, Hieracium humile, Hieracium pannosum, Laserpitium siler, Leontopodium alpinum, Saxifraga tridactylites, or Silene saxifraga. This circumstance was observed and recently discussed by Surina \& Martinčič (2012). Nevertheless, low coverage and fidelity indices of chasmophytes in the studied stands do not justify their classification within the class Asplenietea trichomanis.

Finaly, the syntaxonomical position of the Carici laevis-Helianthemetum alpestre seslerietosum tenuifoliae from Mt. Šarplanina remains unclear, given that in the DCA analysis its stands are overlapping with the stands of associations from Bosnian and Montenegrin mountains. A possible reason for this is the fact that this subassociation was described on the basis of only three relevés, which is not representative enough for an objective understanding of its syntaxonomical position. While all of the other investigated syntaxa are found within the Dinaric floristic province, the stands of this subassociation belong to the Scardo-Pindic floristic province. Accordingly, the comparison of these three relevés with the rest of the 136 dinaric relevés would not reflect the real relationships of these syntaxa within the Balkan Peninsula.

\section{ACKNOWLEDGEMENTS}

The authors are grateful to the Serbian Ministry of Science and Technological Development (Project No. 173030 Biodiversity of the plant life of Serbia and Balkan Peninsula - Assessment, sustainable use and conservation, 2011-2014) for financial support. The authors also wish to thank Jozef Šibík, Kiril Vassilev and Jürgen Dengler for their valuable comments and suggestions, which have significantly improved this manuscript. Finally, we thank Laura Sutcliffe for the linguistic editing of the manuscript and EDGG for making this possible through an IAVS grant. 


\section{REFERENCES}

Aćić, S., Petrović, M., Dajić Stevanović, Z. \& Šilc, U. 2012: Vegetation Database Grassland Vegetation in Serbia. Biodiversity \& Ecology 4: 418-418.

Alegro, A. 2007: Systematics and distribution of Sesleria juncifolia complex in the Dinaric area. PhD Thesis, Department of Biology, Faculty of Science, University of Zagreb, Zagreb, $124 \mathrm{pp}$.

Braun-Blanquet, J. 1964: Pflanzensoziologie. Grundzüge der Vegetationskunde. 3rd ed. Springer, Wien, 865 pp.

Chytrý, M. \& Otýpková, Z. 2003: Plot sizes used for phytosociological sampling of European vegetation. Journal of Vegetation Science 14: 563-570.

Chytrý, M. \& Tichý, L. 2003: Diagnostic, constant and dominant species of vegetational classes and alliances of the Czech Republic: A statistical revision. Folia Facultatis Scientarum Naturalium Universitatis Masarykianae Brunensis. Biologia 108: 1-231.

Chytrý, M. 2010: Vegetation of the Czech Republic 1. Grassland and heathland vegetation [in Czech, with English summary]. Academia, Praha, 528 pp.

Chytrý, M., Tichý, L., Holt, J. \& Botta-Dukát, Z. 2002: Determination of diagnostic species with statistical fidelity measures. Journal of Vegetation Science 13: 79-90.

Dengler, J. 2003: Entwicklung und Bewertung neuer Ansätze in der Pflanzensoziologie unter besonderer Berücksichtigung der Vegetationsklassifikation. Archiv naturwissenschaftlicher Dissertationen 14. Galunder, Nümbrecht, 297 pp.

Deyl, M. 1980: Sesleria Scop. In: Tutin, T. G., Heywood, V. H., Burges, N.A., Moore, D. M., Valentine, D. H., Walters, S. M. \& Webb, D. A. (eds.): Flora Europea 5 (Alismataceae to Orchidaceae). Cambridge University Press, Cambridge, pp. 173-177.

Di Pietro R., Kabaš E., Vukojičić S., Fortini P., Alegro A., Kuzmanović N., Lakušić D. \& Surina B. 2013: Phytosociological features of the amphi-Adriatic Sesleria juncifolia s.l. grasslands. 35th meeting Eastern Alpine and Dinaric Society for Vegetation Ecology. Ohrid (Republic of Macedonia), July 3-6 2013. Book of abstracts. Macedonian Academy of Sciences and Arts, Jovan Hadži Institue of Biology ZRC SAZU, Anton Melik Geographical Insti- tute ZRC SAZU, ZRC Publishing house, Ljubljana and Skopje, pp. 9-9.

Di Pietro, R., Kuzmanović, N., Iamonico, D., Pignotti, L., Barina, Z., Lakušić, D. \& Alegro, A. 2013: Typification of the names in the Sesleria juncifolia species complex (Poaceae). Phytotaxa 152: 18-32.

Flora Europaea Database 2012: Royal Botanic Garden Edinburgh. Retreived November 23, 2012 from http://rbg-web2.rbge.org.uk/FE/ fe.html.

Horvat, I. \& Horvatić, S. 1934: ChrysopogonetoSatureion subspicatae - ein neuer Verband der Brometalia erecti Braun-Blanquet. Acta Botanica Instituti Botanici Regalis Universitatis Zagrebensis 4: 8-12.

Horvat, I. 1930: Vegetation studies of Croatian mountains 1. Associations on mountain barrens. Work of Yugoslavian Academy 238: 1-87.

Horvat, I., Glavač, V. \& Ellenberg, H. 1974: Vegetation Südosteuropas. Geobotanica Selecta 4. Gustav Fischer Verlag, Stuttgart, 768 pp.

Jarolímek, I. \& Šibík, J. (eds.) 2008: Diagnostic, constant and dominant species of the higher 367 vegetation units of Slovakia. Veda, Bratislava, $329 \mathrm{pp}$.

Jovanović, B., Lakušić, R., Rizovski, R., Trinajstić, I. \& Zupančić, M. (eds.) 1986: Prodromus phytocenosum Yugoslaviae ad mappam vegetationis 1: 200 000. Scientific Council of the Vegetation Maps of Yugoslavia, Bribir - Ilok, $46 \mathrm{pp}$.

Karadžić, B., Šašo-Jovanović, V., Jovanović, Z. \& Popović, R. 1998: FLORA - a database and software for floristic and vegetation analyzes. In: Tsekos, I. \& Moustakas, M. (eds.): Progress in botanical research. Kluwer Academic Publishers, Dodrecht, pp. 69-72.

Klika, J. \& Hadač, E. 1944: Rostlinná společenstva střední Evropy [in Czech]. Prŕroda (Praha) 36: 249-259.

Koch, W. 1926: Die Vegetationseinheiten der Linthebene unter Berücksichtigung der Verhältnisse in der Nordostschweiz, Zollikofer, St. Gallen, 144 pp.

Lakušić, R. 1966: Vegetation of meadows and pastures on Mt. Bjelasica. The Yearbook of Biological Institute of University Sarajevo 19: 25-186.

Lakušić, D. \& Sabovljević, M. 2005: Phytocoenological classification of vegetation. In: Lakušić, D. (ed.): Habitats in Serbia, results of the project "Harmonization of national nomenclature 
in the classification of habitats with the international standards" (In Serbian). Institute of Botany and Botanical Garden "Jevremovac", Faculty of Biology, University of Belgrade, Ministry of Science and Environmental protection of the Republic of Serbia. URL: http:// habitat.bio.bg.ac.rs/nacionalne_klasifikacije_stanista.htm [accessed: 8 July 2012].

Lakušić, R., Pavlović, D., Abadžić, S., Kutleša, L. \& Mišić, L. 1982: Die Ökosysteme des Gebirges Vlašić. Bulletin der Ökologischen Gesellschaft Bosniens und der Herzegovina, Seria A, 1: 7-131.

Lausi, D., Gerdol, R. \& Piccoli, F. 1982: Syntaxonomy of the Ostrya carpinifolia woods in the Southern Alps (N Italy) based on numerical methods. Studia Geobotanica 2: 41-58.

McCune, B. \& Mefford, M. J. 2011: PC-ORD for windows: multivariate analysis of ecological data 6. MjM Software, Gleneden Beach.

McNeill, J., Barrie, F. R., Buck, W. R., Demoulin, V., Greuter, D. L., Hawksworth, D. L., Herendeen, P. S., Knapp, S., Marhold, K., Prado, J., Proud'Homme van Reine, W. F., Smith, J. F. \& Wiersema, J. H. (eds.) (2012) International Code of Nomenclature for algae, fungi and plants (Melbourne Code): Adopted by the Eighteenth International Botanical Congress, Melbourne, Australia, July 2011. Regnum Vegetabile 154. Koeltz, Königstein, 240 pp.

Petković, B., Tatić, B., Marin, P. D. \& Dimić, J. 1990: Contribution to the knowledge of communities of Edraianthus jugoslavicus Lakušić from Mokra Gora (Southwest Serbia). Bulletin der Ökologischen gesellschaft Bosniens und der Herzegovina, Seria B, 5: 131-135.

Petriccione, B. 1995: Survey of high mountain basiphilous dry meadow of Euopre convergences and differences. Annali di Botanica 53: 49-57.

Rajevski, L. 1990: Phytocoenological characteristics of mountain pastures of the northern side of Sarplanina mountain. Bulletin de l'Institut et du jardin botaniques de l'Universite de Beograd 10: 1-62.

Redžić, S., Lakušić, R., Muratspahić, D., Bjelčić, Ž. \& Omerović, S. 1984: Structure and dynamics of phytocoenoses in the ecosystems on mountains Cincar and Vitorog. The Yearbook of Biological Institute of University Sarajevo 37: 123-177.

Rodwell, J. S., Schaminee, J. H. J., Mucina, L., Pignatti, S., Dring, J. \& Moos, D. 2002: The
Diversity of European Vegeation. An overview of phytosocological alliances and their relationships to EUNIS habitats. Report EC-LNV nr. 2002/54. National Reference Centre for Agriculture, Nature and Fisheries, Wageningen, $168 \mathrm{pp}$.

Stanić, S. 1990: The analysis of flora and vegetation of rocky crevices, rocky grounds and screes of Mt. Mučanj. Diploma thesis, Department of Plant Ecology and Geography, Faculty of Biology, University of Belgrade, Belgrade, $87 \mathrm{pp}$.

Stanić, S. \& Lakušić, D. 1993: Edraiantho jugoslavicii-Hieracietum humile and Carici laevis-Leontopodietum alpinii, the new chasmophytic communities on the limestone of Mučanj mountain (SW Serbia). Bulletin de l'Institut et du jardin botaniques de l'Universite de Beograd 24-25: 21-32. Strgar, V. 1981: Die Sippenstruktur von Sesleria auf der Balkanhalbinsel. Botanische Jahrbücher für Systematik, Pflanzengeschichte und Pflanzengeographie, 102: 215-224.

Surina, B. \& Martinčič, A. 2012: Chasmophytes on screes. A rule and not an exception in the vegetation of the Karst (south-west Slovenia). Plant Biosystems 146: 1078-1091.

Surina, B. 2013: Heaths with dwarf ericaceous shrubs and Alpine juniper (funiperus alpina) in the Dinaric Alps: A nomenclatorial and synsystematic re-appraisal. Acta Botanica Croatica 72: 113-132.

Tichý, L. \& Chytrý, M. 2006: Statistical determination of diagnostic species for site groups of unequal size. Journal of Vegetation Science 17: 809-818.

Trinajstić, I. 1987: The syntaxonomical review of plant communities of Mt. Biokovo. Acta Biocovica 4: 143-174.

Tutin, T. G., Heywood, V. H., Burges, N. A.; Valentine, D. H., Walters, S. M. \& Webb, D. A. 2001: Flora Europaea on CD-ROM. Cambridge University Press, Cambridge.

van der Maarel, E. 1979: Transformation of coverabundance values in phytosociology and its effects on community similarity. Vegetatio 39 : 97-114.

Received: 7. 3. 2013

Accepted: 23. 2. 2014

Co-ordinating editor: Jürgen Dengler 
Table 1: Analysed syntaxa dominated by Sesleria juncifola agg. from the Balkan Peninsula used in the analysis.

Tabela 1: Proučevani sintaksoni v katerih prevladuje Sesleria juncifola agg. z Balkanskega polotoka uporabljeni v analizi.

\begin{tabular}{|c|c|c|c|c|c|c|}
\hline No. & Syntaxon & UTM & Locality & Reference & $\begin{array}{c}\text { Plot size } \\
\left(\mathrm{m}^{2}\right)\end{array}$ & $\begin{array}{l}\text { Number } \\
\text { of relevés }\end{array}$ \\
\hline 1. & $\begin{array}{l}\text { Rhododendro hirsuti-Juniperetum } \\
\text { alpinae Horvat ex Horvat et al. } 1974 \\
\text { subas. seslerietosum tenuifoliae } \\
\text { Surina } 2013\end{array}$ & 33T VL53 & $\begin{array}{c}\text { Slovenia } \\
\text { (Liburnian } \\
\text { karst), Croatia } \\
\text { (Liburnian karst) }\end{array}$ & $\begin{array}{l}\text { Surina } \\
2013\end{array}$ & 30 & 13 \\
\hline 2. & $\begin{array}{l}\text { Seslerio-Edraianthetum jugoslavicii } \\
\text { Petković et al. } 1990\end{array}$ & 34T DN44 & $\begin{array}{l}\text { Serbia (Mt. } \\
\text { Mokra Gora) }\end{array}$ & $\begin{array}{l}\text { Petković } \\
\text { et al. } 1990\end{array}$ & $25-100$ & 5 \\
\hline 3. & $\begin{array}{l}\text { Seslerietum tenuifoliae Stanić \& } \\
\text { D. Lakušić } 1990 \text { prov. }\end{array}$ & 34T DP22 & $\begin{array}{l}\text { Serbia (Mt. } \\
\text { Mučanj) }\end{array}$ & $\begin{array}{l}\text { Vukojičić \& } \\
\text { Lakušić, D. } \\
\text { unpubl. }\end{array}$ & $20-400$ & 12 \\
\hline 4,5 & $\begin{array}{l}\text { Seslerietum juncifoliae } \\
\text { Horvat } 1930\end{array}$ & 33T XJ66 & $\begin{array}{l}\text { Bosnia and } \\
\text { Herzegovina } \\
\text { (Mt. Cincar) }\end{array}$ & $\begin{array}{l}\text { Lakušić et al. } \\
\qquad 1984\end{array}$ & $20-100$ & 24 \\
\hline 6. & $\begin{array}{l}\text { Seslerio-Gentianetum dinaricae } \\
\text { Lakušić et al. } 1982\end{array}$ & 33T YK00, YK01 & $\begin{array}{l}\text { Bosnia and } \\
\text { Herzegovina } \\
\text { (Mt. Vlašić) }\end{array}$ & $\begin{array}{l}\text { Lakušić et al. } \\
\qquad 1982\end{array}$ & $10-100$ & 10 \\
\hline 7. & $\begin{array}{c}\text { Carici laevis-Helianthemetum } \\
\text { alpestre Horvat } 1930 \text { subas. } \\
\text { seslerietosum tenuifoliae } \\
\text { Rajevski } 1990\end{array}$ & 34T EM07 & $\begin{array}{l}\text { Serbia (Mt. Šar- } \\
\text { planina) }\end{array}$ & $\begin{array}{l}\text { Rajevski } \\
1990\end{array}$ & - & 3 \\
\hline 8. & $\begin{array}{c}\text { Carici humilis-Seslerietum } \\
\text { juncifoliae }\end{array}$ & 33T VK95 & $\begin{array}{l}\text { Croatia (northern } \\
\text { part of Mt. } \\
\text { Velebit) }\end{array}$ & $\begin{array}{c}\text { Alegro } \\
\& \text { Segota } \\
2009,2010 \\
\text { manuscript }\end{array}$ & 50 & 9 \\
\hline 9. & $\begin{array}{l}\text { Carici laevis-Seslerietum tenuifoliae } \\
\text { (Lakušić 1966) Redžić } 2011 \\
\text { (=Seslerietum juncifoliae } \\
\text { montenegrinum Lakušić 1964) }\end{array}$ & 34T CN94 & $\begin{array}{l}\text { Montenegro } \\
\text { (Mt. Bjelasica) }\end{array}$ & $\begin{array}{c}\text { Lakušić } \\
1966\end{array}$ & $100-200$ & 10 \\
\hline 10. & Seslerietum juncifoliae s.1. & $\begin{array}{l}\text { 34T DN46, DN47, } \\
\text { DN48 }\end{array}$ & $\begin{array}{l}\text { Montenegro (Mt. } \\
\text { Durmitor) }\end{array}$ & $\begin{array}{l}\text { Lakušić, D., } \\
\text { unpubl. }\end{array}$ & $20-100$ & 5 \\
\hline 11. & $\begin{array}{l}\text { Genisto sericeae-Seslerietum } \\
\text { juncifoliae Poldini } 1980\end{array}$ & $\begin{array}{l}\text { 33T UL96, VL06, } \\
\text { VL13, VL14, VL15, } \\
\text { VL23, VL26, VL27, } \\
\text { VL44 }\end{array}$ & $\begin{array}{l}\text { Slovenia } \\
\text { (Liburnian } \\
\text { karst), Italy } \\
\text { (Karst) }\end{array}$ & $\begin{array}{l}\text { Poldini } 1989, \\
\text { Kaligarič } \\
1997\end{array}$ & $70-80$ & 19 \\
\hline 12. & $\begin{array}{l}\text { Carici humilis-Centaureetum } \\
\text { rupestris Horvat } 1931 \text { seslerietosum } \\
\text { juncifoliae Horvat } 1962\end{array}$ & $\begin{array}{l}\text { 33T VL13, VL15, } \\
\text { VL23, VL24, VL26, } \\
\text { VL27, VL44, VL54 }\end{array}$ & $\begin{array}{l}\text { Slovenia } \\
\text { (Liburnian } \\
\text { karst), Italy } \\
\text { (Karst) }\end{array}$ & $\begin{array}{l}\text { Poldini } 1989, \\
\text { Kaligarič } \\
\text { 1997, Surina } \\
\text { unpubl. }\end{array}$ & 100 & 25 \\
\hline 13. & $\begin{array}{c}\text { Bromo-Seslerietum interruptae } \\
\text { Trinajstić } 1965\end{array}$ & 33Т XH69 & $\begin{array}{c}\text { Croatia } \\
\text { (Mt. Biokovo) }\end{array}$ & $\begin{array}{c}\text { Trinajstić } \\
1987\end{array}$ & - & 4 \\
\hline
\end{tabular}


Table 2: Analytical table of the association Diantho petraeae-Seslerietum juncifoliae ass. nova. from Mt. Mučanj in Serbia. Species are sorted in descending order of constancy and cover values. ( ${ }^{*}=$ holotypus).

Tabela 2: Analitična tabela asociacije Diantho petraeae-Seslerietum juncifoliae ass. nova. z gore Mučanj v Srbiji. Vrste so razvrščene padajoče glede na stalnost in pokrovnost ( ${ }^{*}=$ holotip).

\begin{tabular}{|c|c|c|c|c|c|c|c|c|c|c|c|c|c|c|}
\hline Altitude (m a.s.l.) & 1450 & 1400 & 1450 & 1450 & 1450 & 1450 & 1450 & 1450 & 1450 & 1350 & 1350 & 1300 & \multirow{8}{*}{\multicolumn{2}{|c|}{ 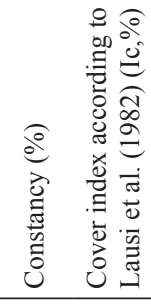 }} \\
\hline Exposition & - & - & W & NW & NW & NW & W & $\mathrm{NE}$ & NW & E & $\mathrm{E}$ & S & & \\
\hline Slope $\left(^{\circ}\right)$ & 0 & 0 & 10 & 10 & 10 & 30 & 70 & 70 & 70 & 50 & 65 & 70 & & \\
\hline Total cover $(\%)$ & 60 & 60 & 80 & 80 & 80 & 50 & 80 & 70 & 60 & 60 & 80 & 25 & & \\
\hline Plot size $\left(\mathrm{m}^{2}\right)$ & 25 & 25 & 100 & 20 & 30 & 75 & 24 & 80 & 30 & 400 & 50 & 30 & & \\
\hline \multirow{2}{*}{ Date } & VII & VII & VII & VII & VII & VII & VII & VII & VII & VII & VII & VII & & \\
\hline & 1989 & 1989 & 1989 & 1989 & 1989 & 1989 & 1989 & 1989 & 1989 & 1989 & 1989 & 1989 & & \\
\hline No. Relevé & 1 & 2 & 3 & 4 & $5^{*}$ & 6 & 7 & 8 & 9 & 10 & 11 & 12 & & \\
\hline \multicolumn{15}{|l|}{ Dominant taxa } \\
\hline Sesleria juncifolia agg. & 2.3 & 2.3 & 3.4 & 4.5 & 4.5 & 3.5 & 4.4 & 4.5 & 3.4 & 3.4 & 2.3 & 2.3 & 100 & 4 \\
\hline \multicolumn{15}{|l|}{ Constant taxa } \\
\hline Globularia cordifolia & 3.4 & 3.3 & 1.3 & 1.3 & 1.2 & 1.3 & 1.2 & 1.1 & 3.4 & 1.3 & . & 1.2 & 92 & 33 \\
\hline Edraianthus graminifolius & + & 1.1 & 1.2 & 1.2 & 1.1 & 1.1 & 1.2 & 1.2 & 1.2 & 1.3 & . & 1.1 & 92 & 42 \\
\hline Saxifraga paniculata & . & . & 1.1 & 1.2 & 1.2 & 1.2 & . & 1.1 & . & 1.2 & 1.2 & 1.2 & 67 & 22 \\
\hline Carex kitaibeliana & 1.2 & 1.2 & . & 1.2 & 1.2 & 1.2 & . & 1.2 & 1.2 & . & . & . & 67 & 22 \\
\hline \multicolumn{15}{|l|}{ Diagnostic taxa (*also constant taxa) } \\
\hline Dianthus petraeus subsp. petraeus* & 1.2 & 1.3 & 1.3 & 1.3 & 1.3 & 1.2 & 1.3 & 1.3 & 1.3 & 1.4 & 1.3 & 1.2 & 100 & 33 \\
\hline Chamaecytisus ciliatus* & 1.2 & 1.3 & 1.2 & 1.2 & 1.2 & 1.2 & 1.3 & 1.3 & 1.2 & 1.3 & 1.2 & 1.2 & 92 & 30 \\
\hline Festuca panciciana* & 1.1 & . & 1.2 & 1.2 & 1.2 & 1.2 & 1.2 & 1.2 & . & 1.2 & 2.2 & 1.2 & 92 & 30 \\
\hline Pedicularis heterodonta* & + & 1.1 & 1.1 & 1.1 & 1.1 & 1.1 & 1.1 & 1.1 & 1.1 & + & . & . & 83 & 30 \\
\hline Potentilla cinerea* & 1.2 & . & 1.2 & 1.3 & 1.2 & 1.2 & 1.3 & 1.3 & 1.3 & 1.2 & 1.2 & 1.2 & 83 & 26 \\
\hline Ornithogalum collinum* & 1.1 & . & . & 1.1 & 1.1 & 1.1 & 1.1 & + & + & 1.1 & 1.1 & . & 75 & 23 \\
\hline Cotoneaster integerrimus* & 1.2 & 1.2 & + & + & 1.1 & 1.2 & . & + & . & 1.3 & 1.3 & . & 75 & 22 \\
\hline Campanula rotundifolia* & . & . & . & . & . & . & 1.2 & 1.2 & 1.1 & 1.2 & 1.2 & 1.2 & 75 & 22 \\
\hline Sanguisorba minor subsp. minor & + & . & 1.1 & 1.1 & + & . & 1.1 & 1.1 & . & 1.2 & 1.2 & + & 58 & 19 \\
\hline $\begin{array}{l}\text { Heliantheтum nuттиlarium subsp. } \\
\text { nuтmularium }\end{array}$ & . & 1.1 & . & . & 1.1 & 1.1 & 1.1 & 1.1 & . & . & 1.2 & . & 50 & 16 \\
\hline Draba lasiocarpa & + & . & . & . & . & . & 1.2 & + & . & 1.1 & 1.2 & + & 50 & 16 \\
\hline Chamaespartium sagittale & 1.2 & + & 1.1 & . & . & . & . & . & + & 1.2 & 1.2 & 1.2 & 50 & 15 \\
\hline Galium corrudifolium & . & . & 1.2 & . & 1.2 & 1.2 & 1.3 & . & . & 1.3 & 1.3 & . & 50 & 14 \\
\hline \multicolumn{15}{|l|}{ Other taxa } \\
\hline Bromus erectus & 1.1 & . & 1.2 & 1.2 & 1.1 & 1.1 & 1.2 & . & . & & 1.1 & . & 58 & 19 \\
\hline Minuartia verna & 1.1 & . & 1.2 & 1.2 & 1.2 & . & 1.2 & 1.2 & . & 1.2 & 1.2 & . & 58 & 18 \\
\hline Leontodon crispus subsp. crispus & 1.1 & + & + & . & . & . & . & . & 1.2 & 1.3 & . & . & 50 & 17 \\
\hline Trifolium montanum & 1.2 & 1.1 & 1.1 & . & 1.1 & 1.1 & . & . & . & . & . & . & 42 & 14 \\
\hline Arenaria serpyllifolia subsp. serpyllifolia & 1.2 & . & . & 1.2 & . & . & . & . & . & 1.1 & 1.2 & . & 42 & 13 \\
\hline Trifolium alpestre & 1.1 & . & + & + & . & . & . & . & . & 1.2 & 1.2 & 1.1 & 42 & 12 \\
\hline Euphrasia stricta & 1.1 & . & 1.1 & 1.1 & + & . & . & . & . & 1.1 & . & . & 42 & 10 \\
\hline Asplenium ceterach & . & . & . & . & . & . & . & . & . & 1.1 & 1.1 & 1.1 & 33 & 11 \\
\hline Juniperus communis & . & + & . & . & . & 1.2 & . & . & . & 1.2 & . & + & 33 & 11 \\
\hline Poa alpina & 1.1 & . & 1.1 & 1.2 & + & . & . & . & . & . & . & . & 33 & 10 \\
\hline Hieracium pilosella subsp. pilosella & . & . & . & 1.2 & . & 1.2 & 1.1 & . & . & . & . & . & 33 & 9 \\
\hline Saxifraga tridactylites & . & . & . & 1.1 & 1.1 & . & 1.1 & . & . & 1.1 & . & . & 33 & 9 \\
\hline Gymnadenia conopsea & + & + & . & . & + & 1.1 & . & + & . & . & . & . & 25 & 8 \\
\hline Rhamnus saxatilis subsp. saxatilis & . & . & . & . & . & . & . & . & . & 1.3 & 1.3 & 1.2 & 25 & 8 \\
\hline Stachys recta & . & . & . & . & . & . & . & . & . & 1.2 & 1.2 & 1.2 & 25 & 8 \\
\hline Sedum acre & . & . & . & + & . & . & . & . & . & 1.2 & 1.2 & + & 25 & 8 \\
\hline Euphorbia myrsinites & . & . & . & . & . & . & . & . & . & . & 2.3 & + & 25 & 8 \\
\hline Rosa pendulina & . & 1.1 & . & . & 1.1 & + & . & . & . & . & . & . & 25 & 8 \\
\hline Asplenium ruta-muraria subsp. ruta-muraria & . & . & . & . & . & + & . & . & . & 1.1 & . & . & 25 & 8 \\
\hline Verbascum sp. & 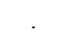 & . & . & . & . & . & . & . & . & 1.2 & 1.1 & 1.1 & 25 & 7 \\
\hline
\end{tabular}




\begin{tabular}{|c|c|c|c|c|c|c|c|c|c|c|c|c|c|c|}
\hline No. Relevé & 1 & 2 & 3 & 4 & $5 *$ & 6 & 7 & 8 & 9 & 10 & 11 & 12 & C. $(\%)$ & Cov. \\
\hline Acinos alpinus & . & . & . & . & . & . & 1.1 & . & . & 1.2 & . & 1.2 & 25 & 7 \\
\hline Teucrium chamaedrys & . & . & . & . & . & . & . & . & . & 1.3 & 1.3 & 1.2 & 25 & 7 \\
\hline Sedum album & . & . & . & . & + & . & . & . & . & 1.2 & 1.2 & . & 25 & 6 \\
\hline Erysimum sylvestre subsp. sylvestre & . & . & . & . & + & + & . & . & . & . & 1.1 & . & 17 & 7 \\
\hline Leontopodium alpinum subsp. alpinum & . & . & . & . & . & 1.2 & . & 1.1 & . & . & . & . & 17 & 6 \\
\hline Arabis hirsuta & . & . & . & . & . & . & . & . & . & 1.1 & 1.2 & . & 17 & 6 \\
\hline Phleum pratense subsp. pratense & . & . & . & . & . & . & . & . & . & 1.1 & 1.3 & . & 17 & 6 \\
\hline Thlaspi kovatsii & . & . & . & . & . & . & 1.1 & 1.1 & . & . & . & . & 17 & 6 \\
\hline Aethionema saxatile subsp. saxatile & . & . & . & . & . & . & . & . & . & 1.1 & 1.2 & . & 17 & 6 \\
\hline Daphne mezereum & . & . & . & . & . & 1.1 & . & . & . & . & . & . & 17 & 6 \\
\hline Thymus pulegioides & . & . & . & . & . & . & 1.1 & . & . & . & . & . & 17 & 6 \\
\hline Vicia incana & . & + & . & . & . & . & . & . & . & . & 1.2 & . & 17 & 6 \\
\hline Cerastium decalvans & . & . & . & . & . & . & . & . & . & 1.2 & 1.2 & . & 17 & 6 \\
\hline Minuartia bosniaca & . & . & . & . & . & . & . & . & . & 1.2 & . & + & 17 & 5 \\
\hline Briza media subsp. media & + & . & . & . & . & 1.1 & . & . & . & . & . & . & 17 & 5 \\
\hline Scabiosa columbaria subsp. columbaria & . & . & 1.1 & . & . & . & . & . & . & 1.1 & . & . & 17 & 5 \\
\hline Hieracium villosum & . & . & . & . & . & . & . & 1.2 & 1.1 & . & . & . & 17 & 5 \\
\hline Poa nemoralis & . & . & . & . & . & 1.3 & 1.2 & . & . & . & . & . & 17 & 4 \\
\hline Rhamnus alpinus subsp. fallax & . & . & . & . & . & . & . & . & . & 1.3 & . & . & 17 & 4 \\
\hline Epipactis atrorubens & . & . & . & . & . & + & + & . & . & . & + & . & 8 & 3 \\
\hline Thymus glabrescens & . & . & + & . & + & . & . & . & . & . & . & . & 8 & 3 \\
\hline Hieracium pannosum & . & . & . & . & . & . & . & . & . & 1.4 & . & . & 8 & 3 \\
\hline Arabis glabra & . & . & . & . & . & . & . & . & . & 1.2 & . & . & 8 & 3 \\
\hline $\begin{array}{l}\text { Cerastium brachypetalum subsp. } \\
\text { brachypetalum }\end{array}$ & . & · & . & . & . & . & . & . & . & . & 1.3 & . & 8 & 3 \\
\hline Arabis alpina & . & . & . & . & . & . & . & . & . & . & 1.3 & . & 8 & 3 \\
\hline Leucanthemum vulgare & . & 1.1 & . & . & . & . & . & . & . & . & . & . & 8 & 3 \\
\hline Plantago lanceolata & . & . & 1.1 & . & . & . & . & . & . & . & . & . & 8 & 3 \\
\hline Plantago media & 1.1 & . & . & . & . & . & . & . & . & . & . & . & 8 & 3 \\
\hline Heracleum sp. & . & . & . & . & . & 1.1 & . & . & . & . & . & . & 8 & 3 \\
\hline Fagus sylvatica & . & . & . & . & . & + & . & . & . & . & . & . & 8 & 3 \\
\hline Valeriana montana & . & . & . & . & . & . & + & . & . & . & . & . & 8 & 3 \\
\hline Myosotis arvensis subsp. arvensis & . & . & . & . & . & . & . & + & . & . & . & . & 8 & 3 \\
\hline Erigeron annuиs & . & . & . & . & . & . & . & . & . & + & . & . & 8 & 3 \\
\hline Sorbus aria & . & . & . & . & + & . & . & . & . & . & . & . & 8 & 3 \\
\hline Hypericum perforatum & . & . & . & . & . & . & . & . & . & + & . & . & 8 & 3 \\
\hline Poa badensis & . & . & . & . & . & . & . & . & . & 1.1 & . & . & 8 & 3 \\
\hline Asperula aristata subsp. scabra & . & . & . & . & . & . & . & . & . & 1.1 & . & . & 8 & 3 \\
\hline Polygala supina subsp. supina & . & . & . & . & . & . & . & . & . & 1.2 & . & . & 8 & 3 \\
\hline Brachypodium pinnatum subsp. pinnatum & . & . & + & . & . & . & . & . & . & . & . & . & 8 & 3 \\
\hline Asplenium trichomanes subsp. trichomanes & . & . & . & . & . & . & . & . & . & . & 1.1 & . & 8 & 3 \\
\hline Lotus corniculatus & + & . & . & . & . & . & . & . & . & . & . & . & 8 & 3 \\
\hline Fragaria vesca & . & . & . & . & . & + & + & . & . & . & . & . & 8 & 2 \\
\hline Allium flavum subsp. flavum & . & . & . & . & . & . & . & . & . & 1.1 & . & . & 8 & 2 \\
\hline Laserpitium siler subsp. siler & . & . & . & . & . & . & . & . & . & 1.3 & . & . & 8 & 2 \\
\hline Vincetoxicum hirundinaria & . & . & . & . & . & . & . & . & . & . & 1.3 & . & 8 & 2 \\
\hline Daphne blagayana & . & 1.2 & . & . & . & . & . & . & . & . & . & . & 8 & 2 \\
\hline Trifolium campestre & . & . & . & . & . & . & . & . & . & + & . & . & 8 & 2 \\
\hline Silene saxifraga & . & . & . & . & . & . & . & . & . & 1.3 & . & . & 8 & 2 \\
\hline Asperula cynanchica & . & . & . & . & . & . & . & . & . & 1.1 & . & . & 8 & 2 \\
\hline Helianthemum canum subsp. canum & . & . & 1.1 & . & . & . & . & . & . & . & . & . & 8 & 2 \\
\hline
\end{tabular}

Relevés 1, 3-9: Serbia, Mt. Mučanj, UTM grid 34T DP22, $43.544924^{\circ} \mathrm{N}, 20.038117^{\circ} \mathrm{E}$

Relevé 2: Serbia, Mt. Mučanj, UTM grid 34T DP22, $43.543552^{\circ} \mathrm{N}, 20.038329^{\circ} \mathrm{E}$

Relevés 10-12: Serbia, Mt. Mučanj, UTM grid 34T DP22, $43.542562^{\circ} \mathrm{N}, 20.038277^{\circ} \mathrm{E}$ 

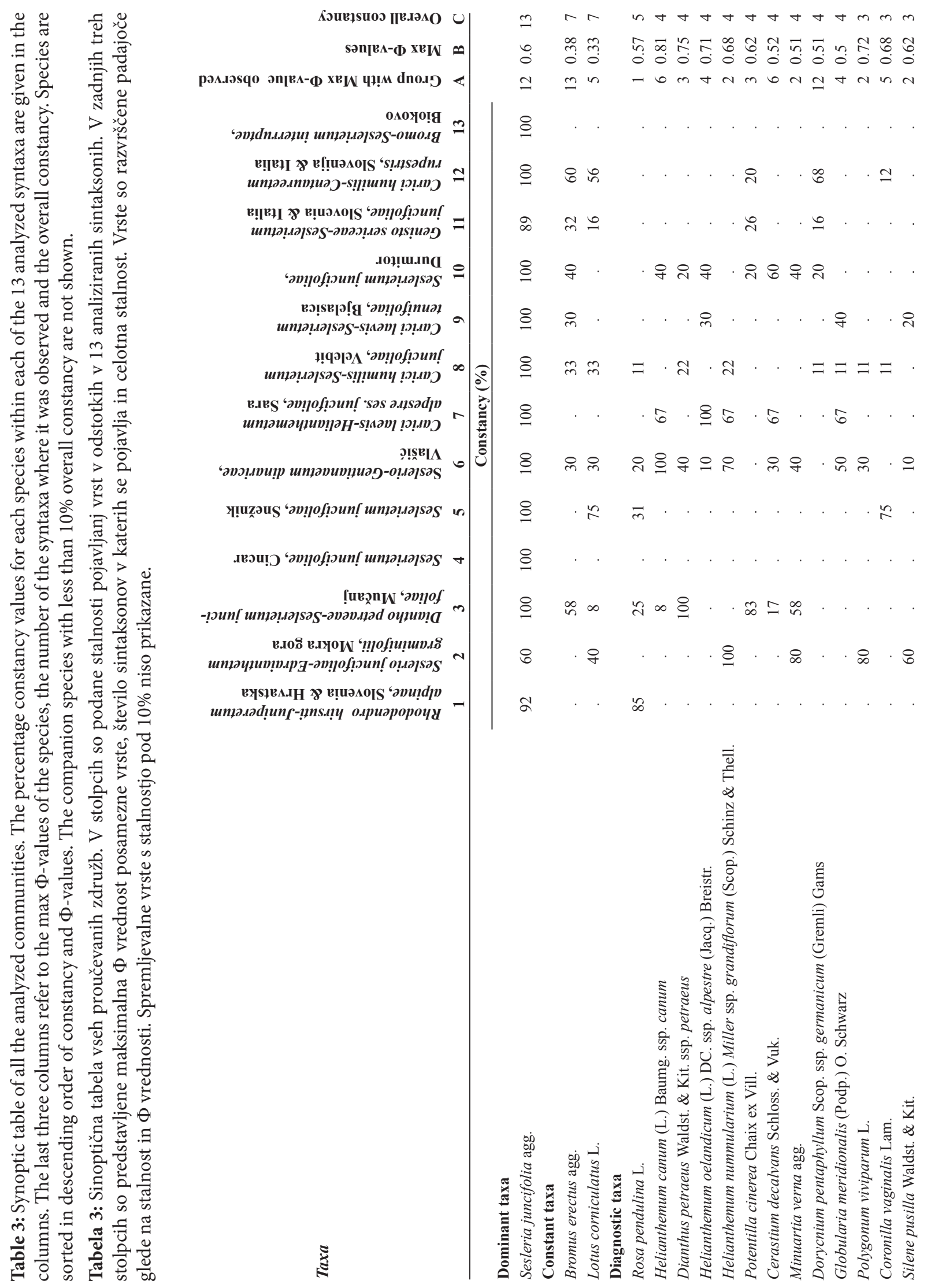


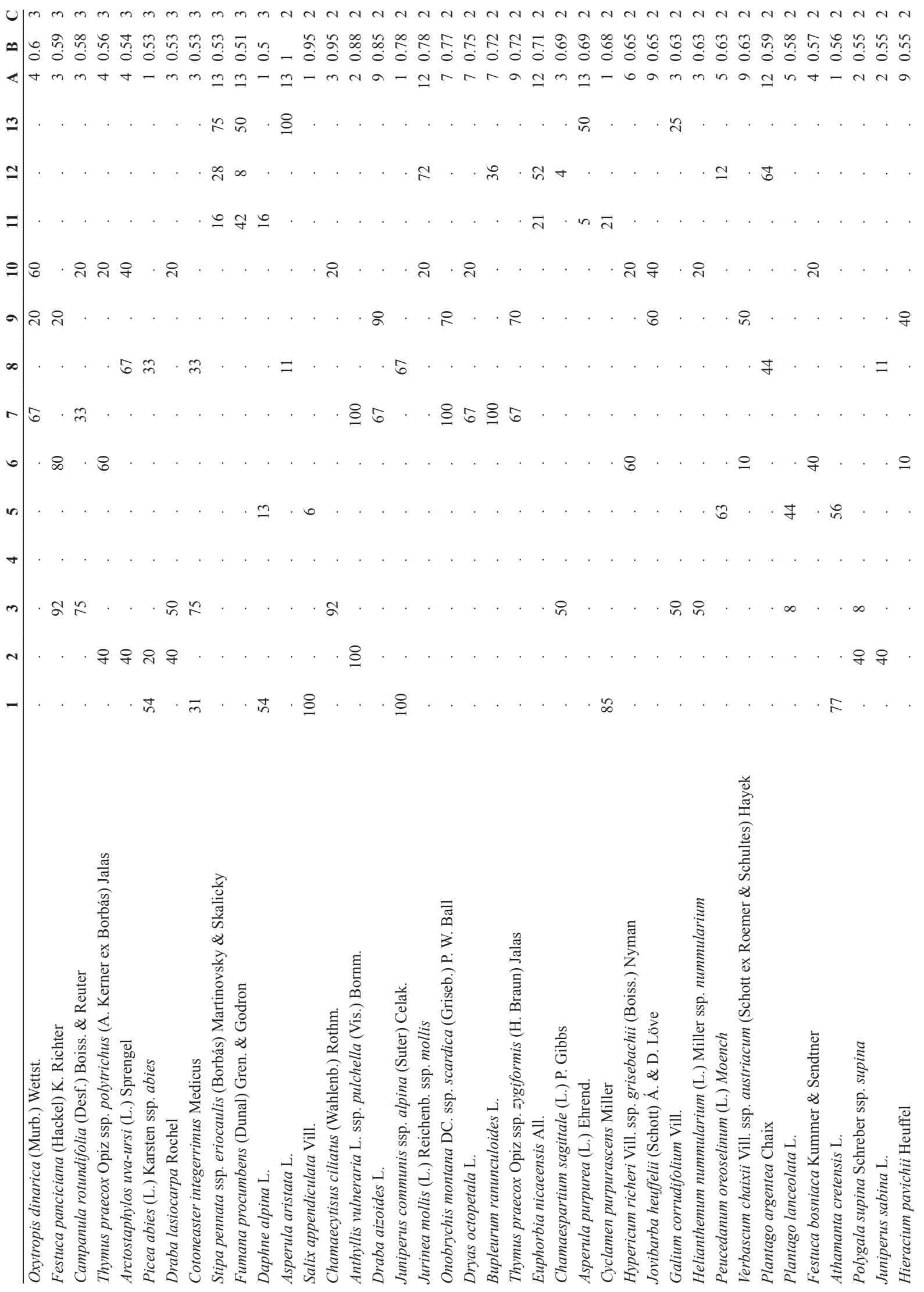




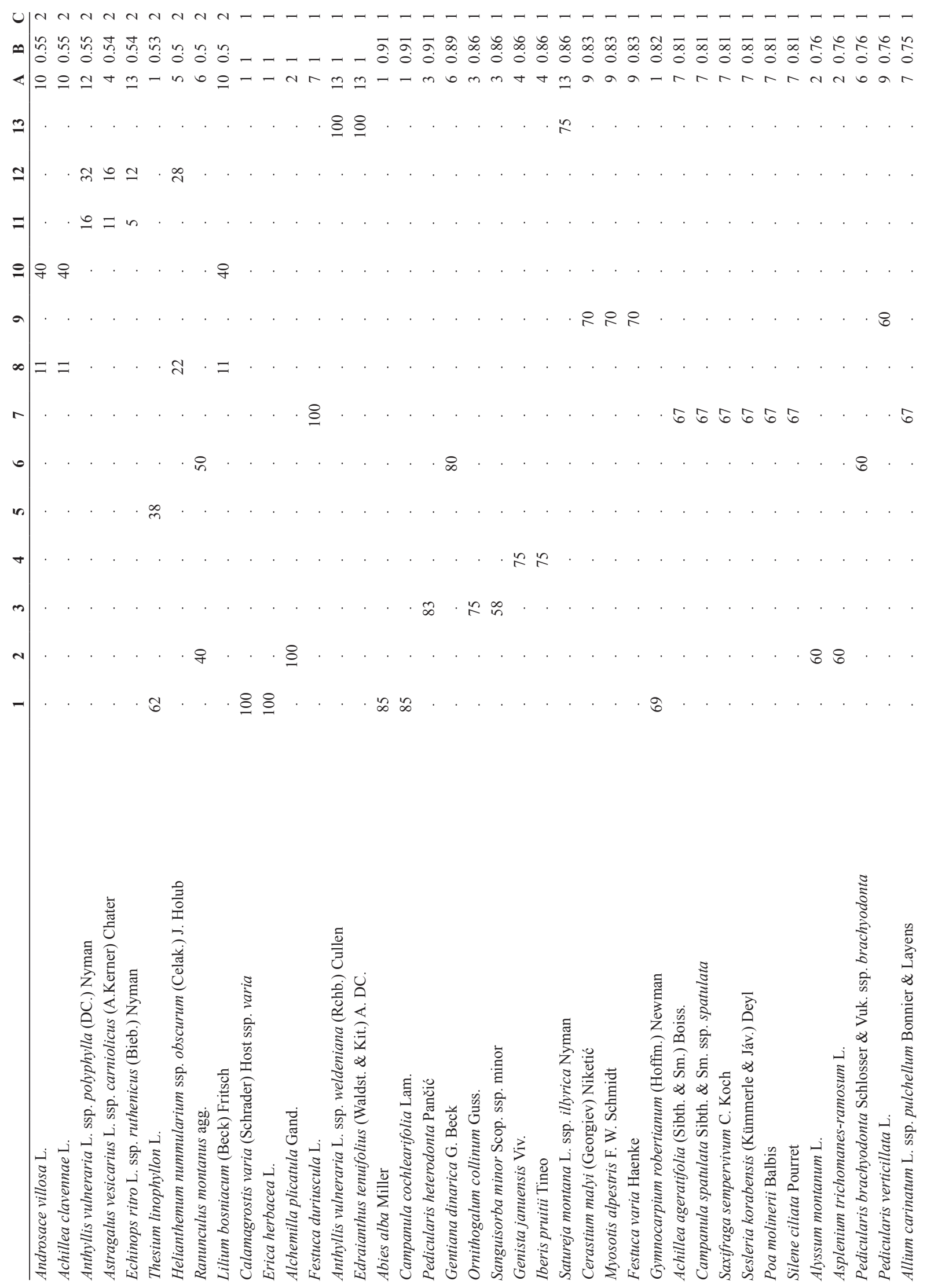




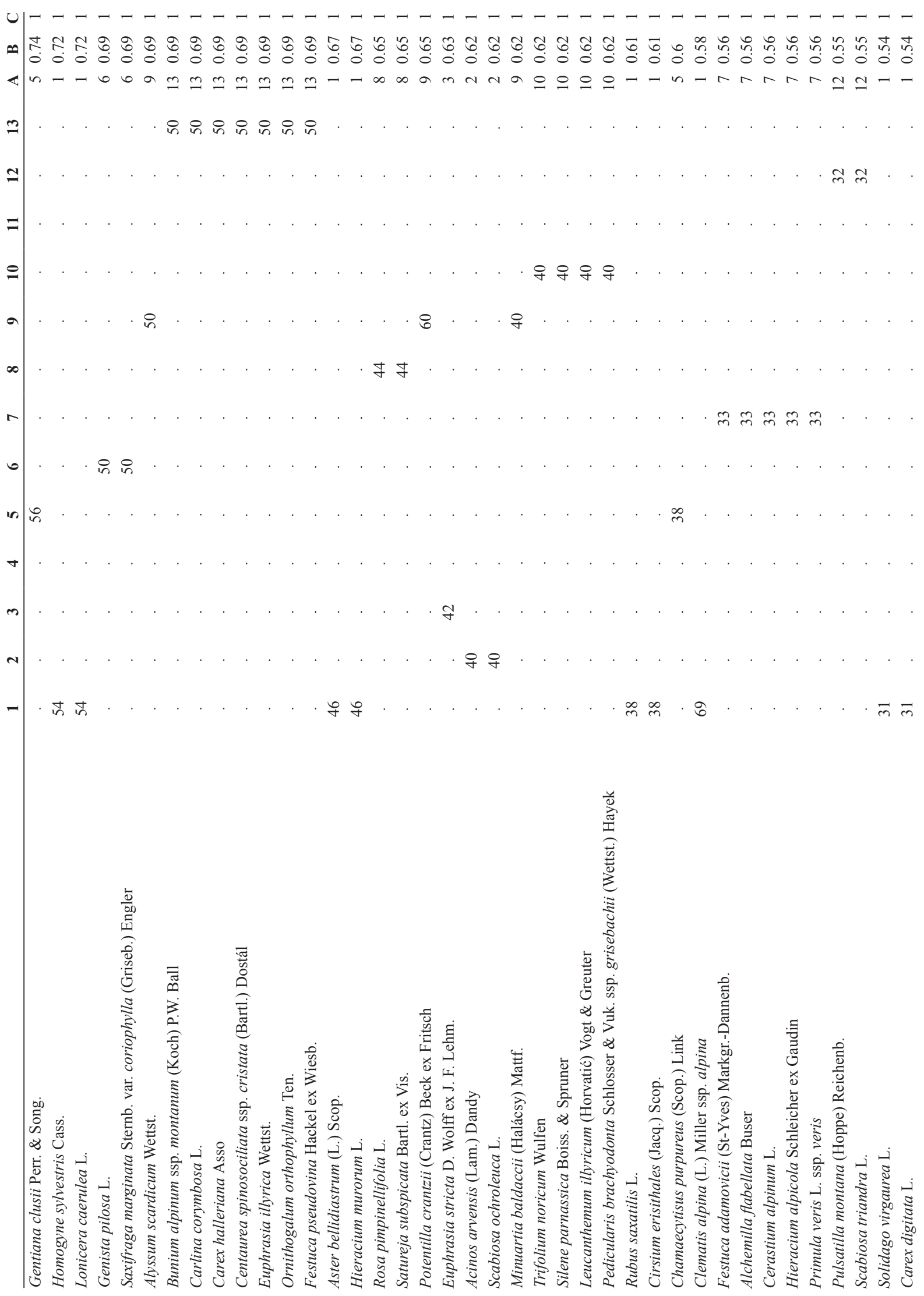




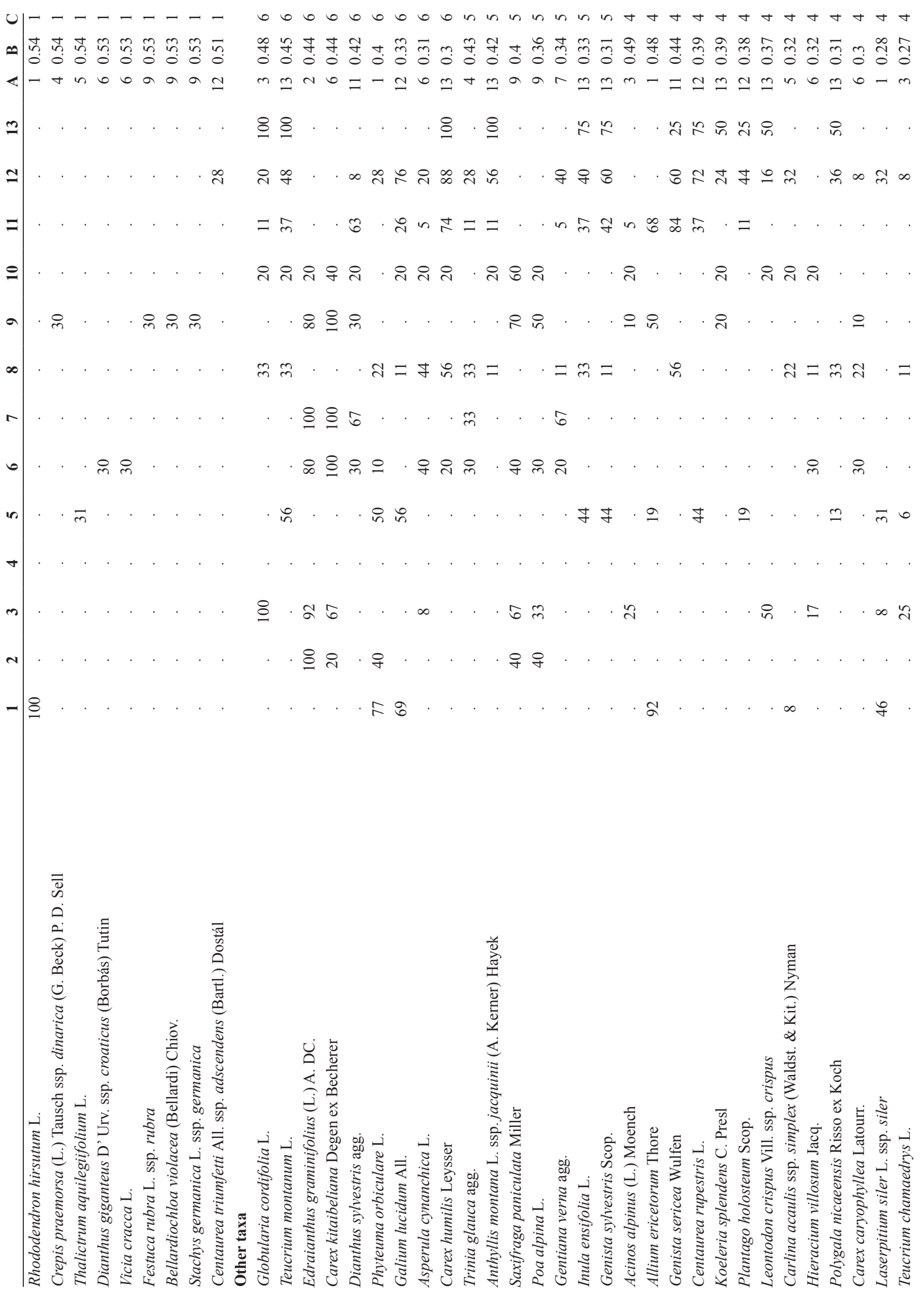




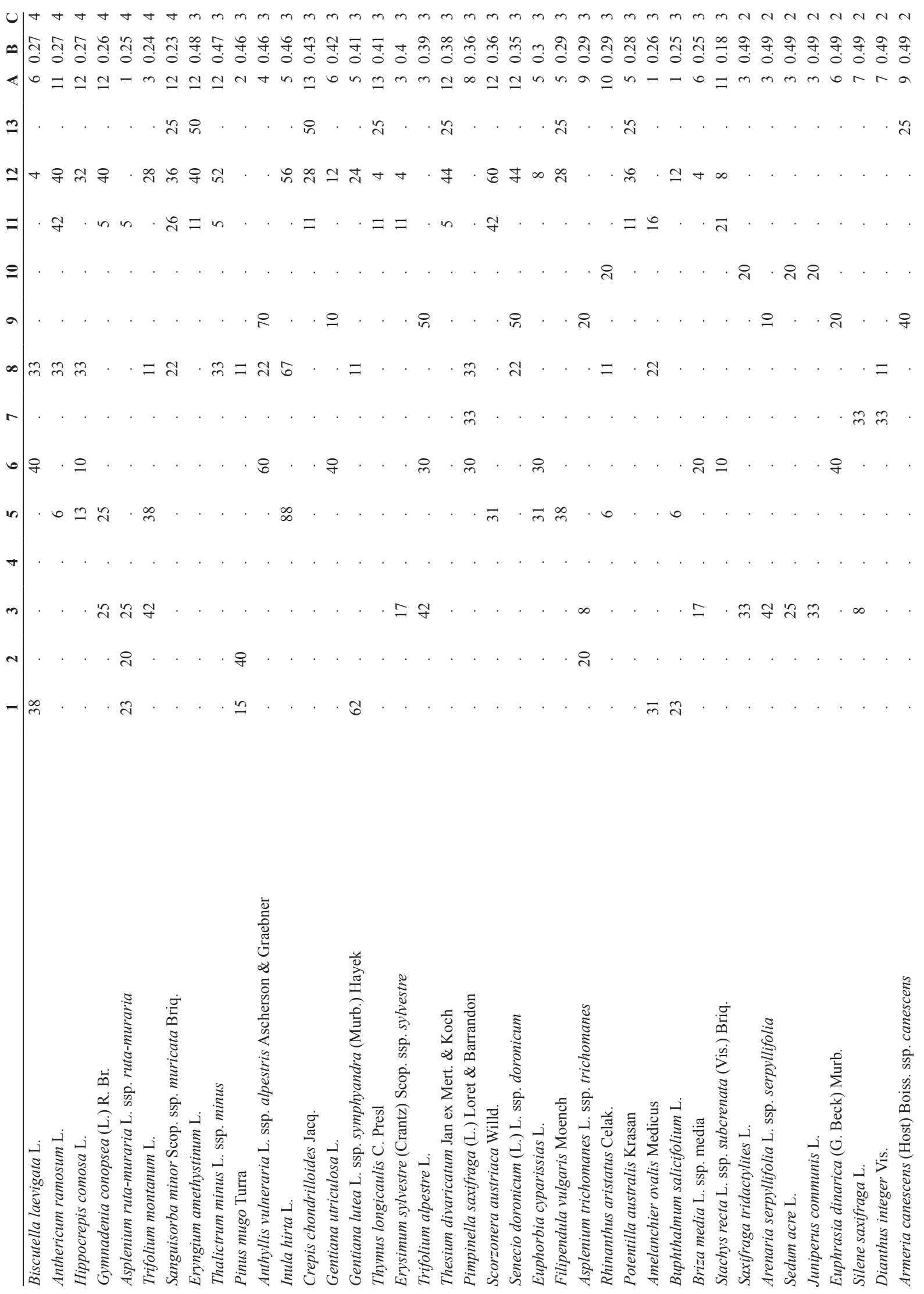




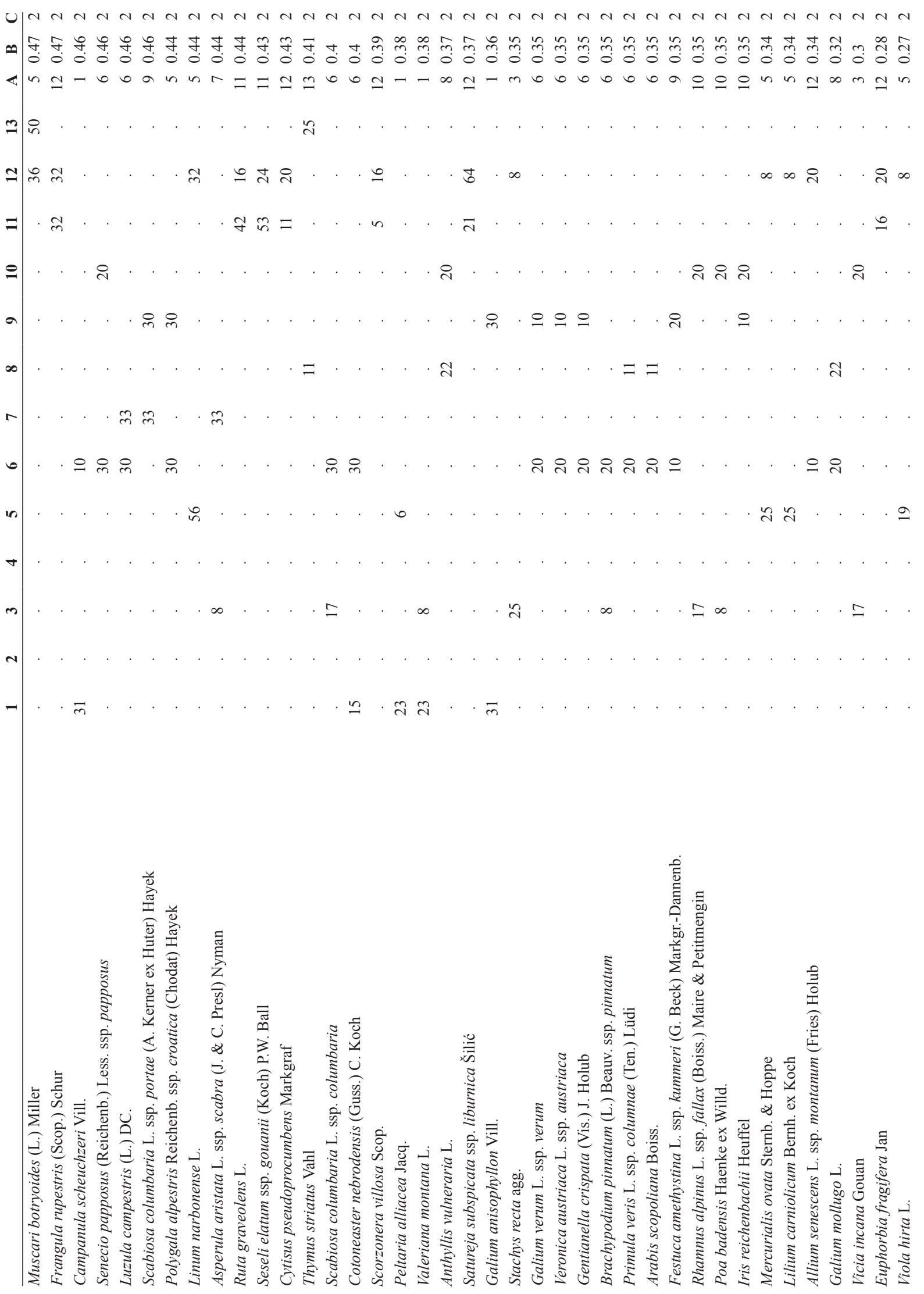




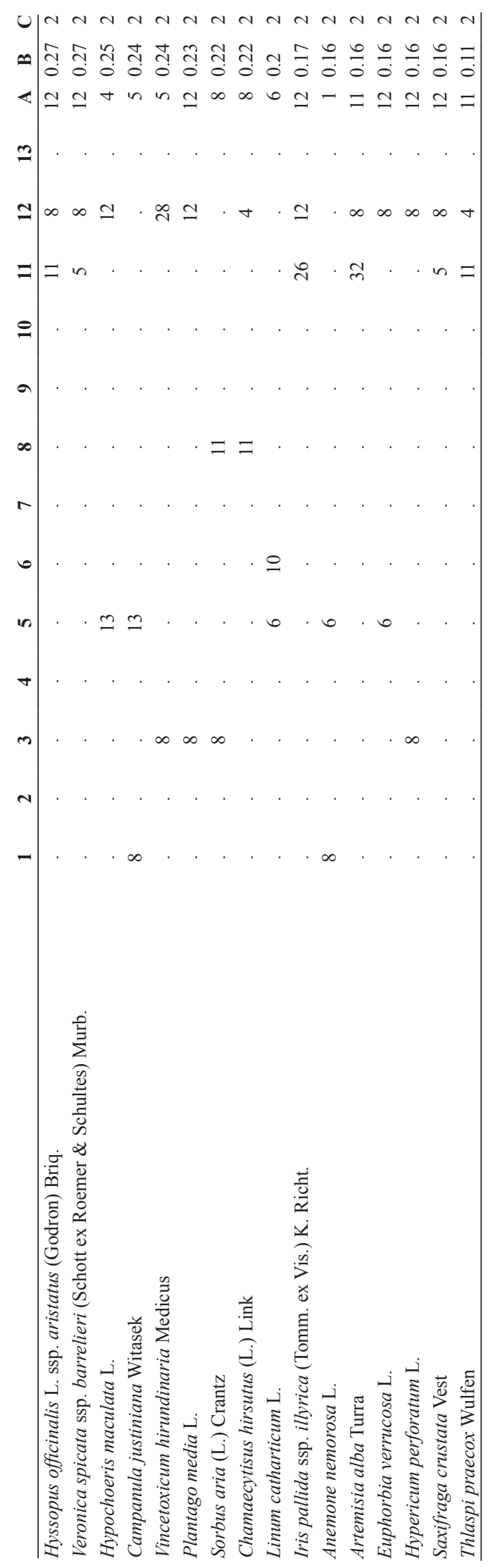

